\section{Mechanical Hedge Pruning Affects Nut Size, Nut Quality, Wind Damage, and Stem Water Potential of Pecan in Humid Conditions}

\author{
Lenny Wells ${ }^{1}$ \\ Department of Horticulture, University of Georgia, Tifton Campus, 4604 \\ Research Way, Tifton, GA 31793
}

Additional index words. Carya illinoinensis, water use, water status, hedging

\begin{abstract}
Recent extensive pecan [Carya illinoinensis (Wangenh.) K. Koch] plantings coincided with a shift toward the planting of pecan trees at higher density by Georgia pecan producers in anticipation of maintaining these densities through hedge pruning. Initial studies of mechanical hedge pruning in the low-light environment of the southeastern United States have failed to show significant benefits to pecan production. The objectives of this study were to compare the effects of hedge pruning on pecan nut quality, yield, and midday stem water potential $(\psi)$ of pecan trees in the temperate climate of the southeastern United States and to evaluate the effect of hedge pruning on windstorm damage to pecan trees. Treatments were arranged in a randomized complete block design with three blocks. Two treatments were evaluated; 1) Hedge-pruned; 2) Nonhedge-pruned (control). Midday stem $\psi$ was $8.5 \%, 17.6 \%$, and $16.6 \%$ higher $(P \leq$ 0.05), indicating less water stress, on hedged trees than on nonhedged trees during 2015 , 2016, and 2017, respectively. Nut weight and percent kernel were increased $(P \leq 0.05)$ by hedge pruning 2 of 3 years of the study. Although no direct positive effect of hedge pruning on in-shell nut yield was observed, hedge pruning was not detrimental to pecan yield in the short term. Hurricane/Tropical Storm Irma brought damaging winds to the entire pecan-producing region of Georgia on 11 Sept. 2017, resulting in blown down trees, broken branches, and immature nuts blown from the trees. Hedged trees had $60 \%$ less wind damage in the form of major limb breakage and tree loss than did nonhedged trees.
\end{abstract}

The profit potential of pecan increased in 2009 with sudden growth in the Asian pecan export market. As a result, there has been a renewed interest in the crop, which has led to the planting of additional pecan acreage throughout the United States pecan belt (USDA, 2012; Wells, 2014). Georgia pecan producers planted at least 391,488 pecan trees and 6203 additional pecan ha from 2010 to 2014. These new plantings coincided with a shift toward the planting of pecan trees at higher density by Georgia pecan producers since 2010 in anticipation of maintaining these densities through hedge pruning (Wells, 2014).

As pecan trees grow in an orchard, their tree canopies encroach on one another, causing excessive shading, which has been shown to increase alternate bearing intensity and reduce tree health and orchard profitability (Pearce and Dobersek-Urbanc, 1967; Wood and Stahmann, 2004). Historically, limb pruning and tree removal have been the solution to this problem, particularly in the low-light environment of the southeastern

Received for publication 15 May 2018. Accepted for publication 18 June 2018.

This work was supported by the Georgia Agricultural Commodity Commission for Pecans.

${ }^{1}$ Corresponding author. E-mail: lwells@uga.edu.

United States (Wells, 2007). Mechanical hedge pruning has been used successfully in high-light environments to mitigate the effects of orchard shading (Wood and Stahmann, 2004) and has become the standard method used for this purpose in the arid production regions of the western United States (Andales et al., 2006; Herrera and White, 2000).

Mature pecan orchard canopies typically intercept $65 \%$ to $70 \%$ of available sunlight (Wood, 1996) with up to 95\% light interception in overcrowded, unpruned orchards (Lombardini, 2006). The southeastern United States is a relatively low-light environment, exhibiting significant cloud cover and atmospheric water vapor throughout the growing season, which can further limit sunlight in orchard systems (Wood, 2009). Initial studies of mechanical hedge pruning in these lowlight environments have failed to show significant benefits to pecan production. Worley (1985) determined that annual cuts to one of each of four sides of the canopy and topping at $6 \mathrm{~m}$ was unsuitable for southeastern commercial pecan orchards. Lombardini (2006) found that one-time mechanical hedge pruning of nonirrigated pecan trees initially increased light within tree canopies but did not increase orchard productivity, nut yield, or quality. Wood (2009) suggested that moderate-width ( $2.4 \mathrm{~m}$ from the tree axis), short-cycle (annual or biennial pruning) mechanical hedging did not appear efficacious for southeastern pecan production in the short term; however, it would be likely that over the long term, it would prove superior to nonpruned trees. Anecdotal experience by pecan producers in the southeastern United States following 2010 suggested a promising approach for mechanical hedge pruning in the region, which has since led to an increase in popularity of the hedge-pruned system among growers (Stevenson, 2013). Bock et al. (2017) found a reduced risk of pecan scab (Fusicladium effusum G. Winter) with hedge pruning of pecans in Georgia as a result of enhanced fungicide coverage through a reduction in tree size.

Pecans are a relatively high water use crop (Wang et al., 2007). As a result, irrigation is one of the most important management tools used in pecan production and results in increased nut size, yield, nut quality, and precocity (Alben, 1957; Brison, 1974; Daniell et al., 1979; Stein et al., 1989; Wells, 2015; Worley, 1982). Water stress in pecan is correlated with soil moisture from budbreak through the end of nut sizing. Pecan trees bearing a moderate to heavy crop load may undergo water stress during the kernel filling stage regardless of soil moisture level (Wells, 2015). Management practices that alleviate water stress have the potential to improve pecan production.

The objectives of this study were to compare the effects of hedge pruning on pecan nut quality, yield, and midday stem water potential of pecan trees in the temperate climate of the southeastern United States and to evaluate the effect of hedge pruning on windstorm damage to pecan trees.

\section{Materials and Methods}

The study was conducted in a buried drip irrigated, commercial 'Desirable' pecan orchard planted in 1996 on a $14.6 \times 14.6-\mathrm{m}$ spacing located in Macon County, GA, near the town of Marshallville (lat. $32^{\circ} 4^{\prime} 33.4^{\prime \prime} \mathrm{N}$, long. $83^{\circ} 14^{\prime} 48.3^{\prime \prime} \mathrm{W}$ ) from 2015 to 2017 . Six 7.6 $\mathrm{L} \cdot \mathrm{h}^{-1}$ drip emitters were ported to the surface $\approx 2 \mathrm{~m}$ from the tree trunk on each side of each tree (12 total emitters per tree) with a distance of $1 \mathrm{~m}$ between emitters. Irrigation was scheduled according to the University of Georgia Cooperative Extension irrigation recommendations for pecan production (Wells, 2017) (Table 1). Irrigation occurred daily throughout the study unless there was a daily rain event of $2.5 \mathrm{~cm}$ or more from April to July and a $5.8 \mathrm{~cm}$ or more rain event from August to September (kernel filling stage). Irrigation was stopped for $3 \mathrm{~d}$ after such rain events occurred.

Soil type was Faceville sandy loam (Fine, kaolinitic, and thermic Typic Kandiudults). The orchard was managed under commercial conditions according to the University of Georgia Cooperative Extension recommendations (Hudson et al., 2017). A 3.7-m-wide vegetation-free strip was maintained with glyphosate along the tree row in all plots. Row middles consisted of nontilled 
bermudagrass (Cynodon dactylon L.) sod. Trees were fertilized according to the University of Georgia cooperative extension recommendations (Wells, 2007). Ammonium nitrate $(34 \mathrm{~N}-0 \mathrm{P}-0 \mathrm{~K})$ was applied to all plots at a rate of $84 \mathrm{~kg} \cdot \mathrm{ha}^{-1} \mathrm{~N}$ on $8 \mathrm{Apr}$. 2015, 4 Apr. 2016, and 3 Apr. 2017. An additional application at a rate of $28 \mathrm{~kg} \cdot \mathrm{ha}^{-1}$ $\mathrm{N}$ was applied on 10 June 2015, 8 June 2016, and 13 June 2017. Zinc sulfate $\left(62.9 \mathrm{~kg} \cdot \mathrm{ha}^{-1}\right)$ $(36 \% \mathrm{Zn})$ was applied to all plots on $31 \mathrm{Mar}$. 2015 . Muriate of potash $\left(70.6 \mathrm{~kg} \cdot \mathrm{ha}^{-1}\right)(52 \%$ K) was applied to all plots on 31 Mar. 2015 and 23 Mar. 2016.

Treatments were arranged in a randomized complete block design with three blocks.

Table 1. Irrigation water application schedule. If the orchard received $2.5 \mathrm{~cm}$ or more of rain per day from 1 Apr. to the onset of kernel filling, the system was turned off for $3 \mathrm{~d}$. Irrigation was switched off for $3 \mathrm{~d}$ during August-September (kernel filling) if the orchard received a $5.8 \mathrm{~cm}$ or more rain event.

\begin{tabular}{lc}
\hline Month & $\begin{array}{c}\text { Irrigation water application } \\
\text { rate (liters per tree per day) }\end{array}$ \\
\hline April & 130 \\
May & 188 \\
June & 260 \\
July & 324 \\
August & 721 \\
September & 721 \\
October & 260 \\
\hline
\end{tabular}

Two treatments were evaluated; 1) Hedgepruned; 2) Nonhedge-pruned (control). Each plot consisted of five contiguous tree rows measuring $420 \mathrm{~m}$ long. Hedge-pruned trees were pruned during February with a commercial hedging machine on one side at $\approx 1.85 \mathrm{~m}$ from the trunk and at the tops of the trees in 2013, 2014, 2016, and 2017. Trees were hedge pruned on their west side in 2013 and 2016 and on their east side in 2014 and 2017. Side pruning removed up to $3.15 \mathrm{~m}$ of growth from the side of the tree being hedge pruned in the year of pruning. The tops of hedgepruned trees were pruned at a $45^{\circ}$ angle to a height of $12 \mathrm{~m}$ on the same side of the tree on which the hedge pruning was done. Nonhedge-pruned trees were $14 \mathrm{~m}$ in height and had a canopy width of $16.4 \mathrm{~m}$.

All data were collected from interior rows within the plots. Midday stem $\psi$ was determined using a pump-up pressure chamber (PMS Instruments, Albany, OR) by measuring the $\psi$ of leaflets located near the trunk or a main scaffold branch, which had been enclosed in a foil-covered bag for $20 \mathrm{~min}$ (Begg and Turner, 1970). Measurements were made every other week between 1300 and $1500 \mathrm{HR}$ from June to September on two trees per plot. One leaflet per tree was measured on each sampling date to keep measurements within close temporal proximity.

Soil moisture was measured with a Field Scout TDR 300 Soil Moisture Meter (Spectrum Technologies, Aurora, IL) at $20 \mathrm{~cm}$ depth within the wetted zone of drip emitters $\approx 0.3 \mathrm{~m}$ from drip emitters and $1.2 \mathrm{~m}$ from the base of the tree on each sampling date at the same time that stem $\psi$ was measured for each tree.

A 50-nut sample was collected from each tree for analysis of individual nut weight and percent kernel. Nuts were shelled and percentage of edible kernel was calculated by dividing the kernel weight for the 50-nut sample by total nut weight.

Pruning effects on resistance to wind damage were evaluated by estimating the percentage of storm-damaged trees in each plot $3 \mathrm{~d}$ following Hurricane Irma's passage through the study site on 11 Sept. 2017 (maximum wind speed of $81.54 \mathrm{~km} \cdot \mathrm{h}^{-1}$ ). This was assessed by counting the number of trees in each row exhibiting large (15.24 $\mathrm{cm}$ diameter) broken limbs and or tree loss and dividing that number by the total number of trees per row. Meteorological data (rainfall and wind speed) were obtained from a University of Georgia Weather Station located $5.3 \mathrm{~km}$ from the study site.

All plots were mechanically harvested separately. In-shell nuts were dried to $4.5 \%$ moisture with a commercial drier and processed in a commercial cleaning plant to remove all sticks, leaves, and debris. All cleaned nuts were then weighed by plot to obtain in-shell nut yield for each plot, which was converted to kilograms per hectare.
A

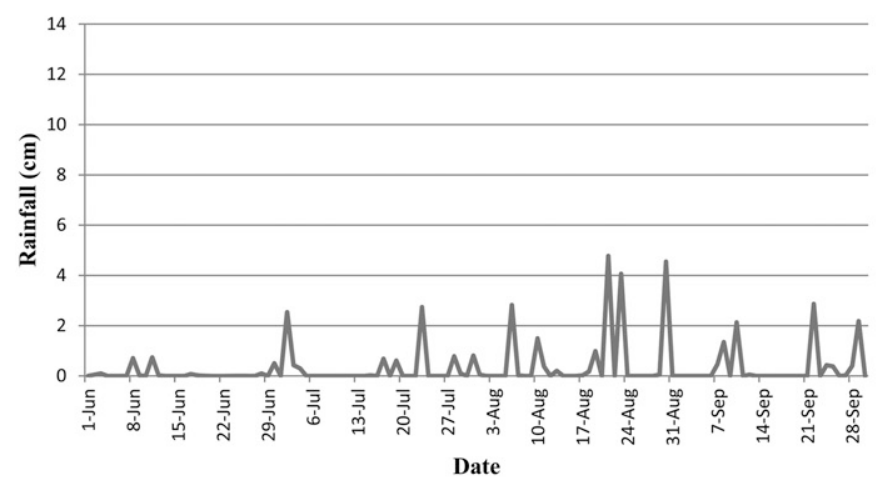

B

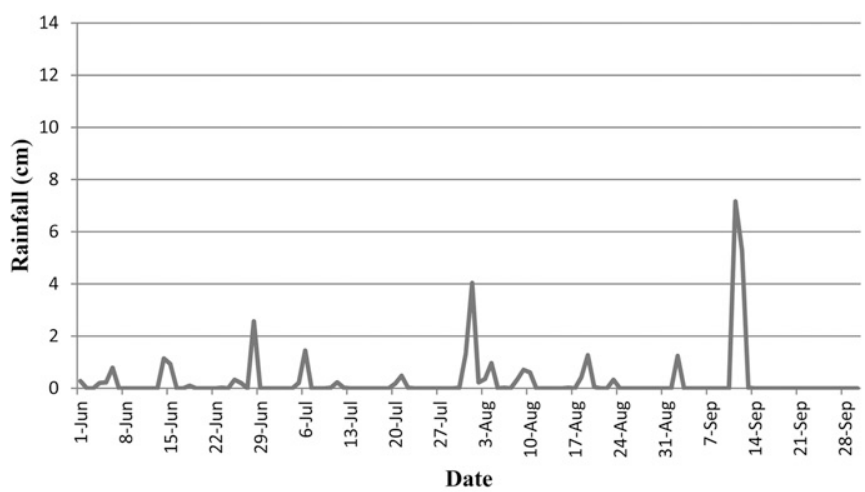

C

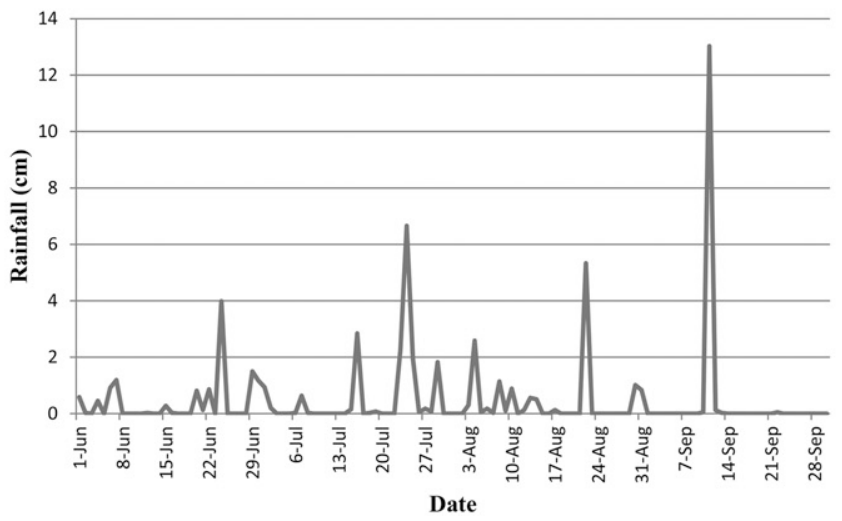

Fig. 1. Daily rainfall distribution from 1 Apr. to 30 Sept. during (A) 2015, (B) 2016, and (C) 2017 at the Ft. Valley State University Weather Station located 5.3 km from the study site. 
All data were analyzed by $t$ test to compare differences between measured variables of hedge-pruned and nonhedge-pruned trees.

\section{Results and Discussion}

Rainfall during the study period was variable. The weather station nearby recorded 41 , 34 , and $57 \mathrm{~cm}$ of rainfall from April to September for 2015, 2016, and 2017, respectively. Rainfall was not evenly distributed throughout the growing season for any of the years of study (Fig. 1), leading to intermittent periods of tree water stress. Othman et al. (2014) have shown that stem $\psi$ of -0.8 to $-0.9 \mathrm{MPa}$ may be the water deficit threshold for prevention of significant reduction in photosynthesis and gas exchange for pecan in the arid environment of New Mexico. Water stress in pecan trees in the more humid southeastern United States is associated with a stem water potential of $\approx-0.78 \mathrm{MPa}$ (Wells, 2015). Midday stem $\psi$ for both treatments was at its lowest point at the end of the kernel filling stage during late September in 2016 and 2017 (Fig. 2). This reflects the increased tree water demand during the kernel filling stage, which has been documented by previous studies (Stein et al., 1989; Wells, 2015). During 2015, periods of water stress were observed during the June and July nut sizing period as well (Fig. 2).

Drip irrigation helped to minimize water stress in both treatments throughout most of each growing season (Fig. 2) and soil moisture was similar for hedged and nonhedged trees throughout the study (Table 2; Fig. 3). Volumetric soil moisture has been previously correlated with stem water potential in Georgia pecan orchards and results of that study suggested that irrigation scheduling for mature pecan trees is needed under southeastern coastal plain conditions when volumetric soil water content reaches $10 \%$ to avoid tree water stress (Wells, 2015). During the present study, volumetric soil moisture only fell below 10\% soil moisture during Aug. and Sept. 2017.

Midday stem $\psi$ was $8.5 \%, 17.6 \%$, and $16.6 \%$ higher $(P \leq 0.05)$, indicating less water stress, on hedged trees than on nonhedged trees during 2015, 2016, and 2017, respectively (Table 2 ). Stem $\psi$ was variable both within and between growing seasons (Fig. 2); however, the nonhedged treatment generally had a lower stem $\psi$ than that of hedged trees. The lower stem $\psi$ in nonhedged trees vs. hedged trees may partially result from a reduction in size of the tree canopy in hedged trees, allowing the root system to support a smaller tree. In almond, overall tree
A

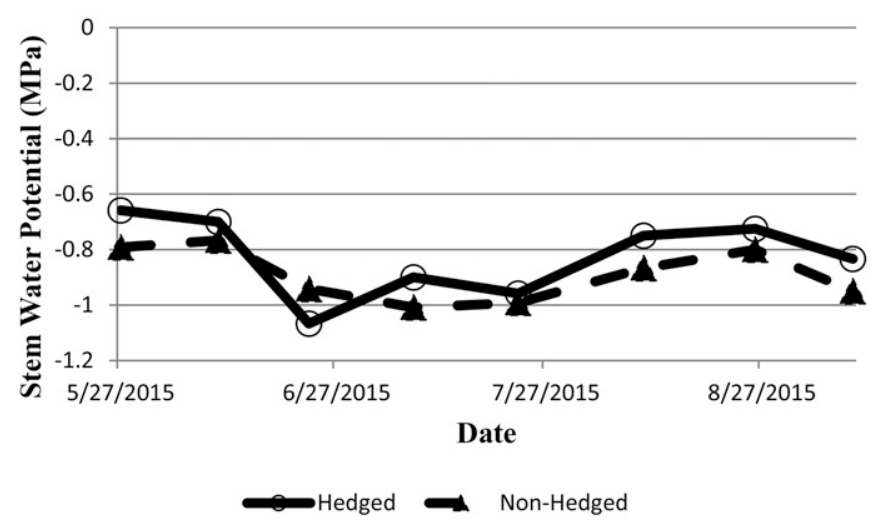

B

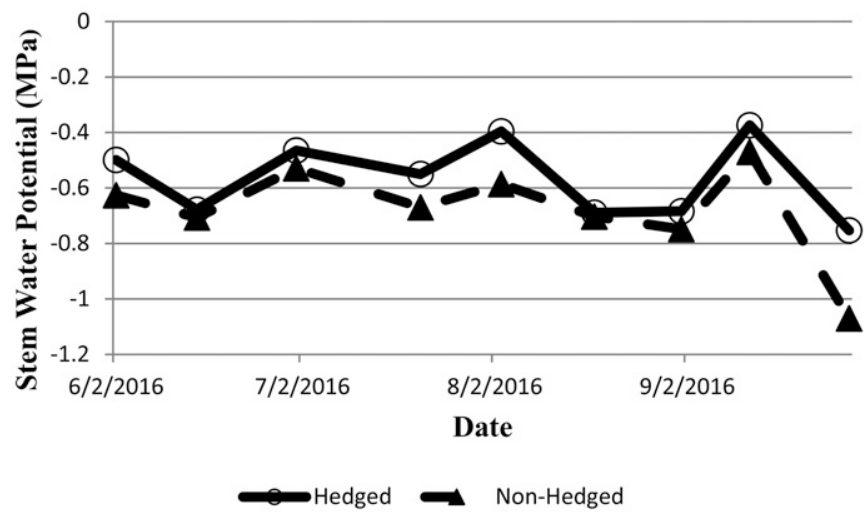

C

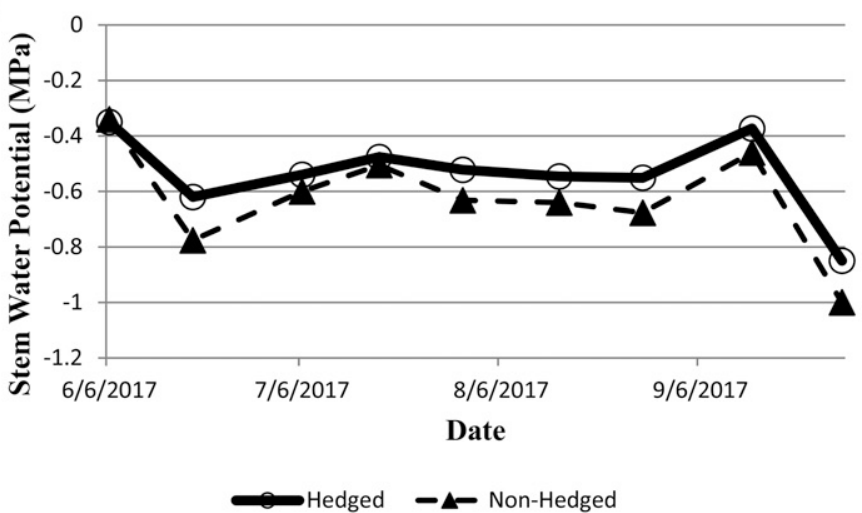

Fig. 2. Mean midday stem water potential $(\psi)$ of hedged and nonhedged 'Desirable' pecan trees during 2015, 2016, and 2017.

Table 2. Mean midday stem water potential, volumetric soil moisture, nut weight, percent kernel, and percent storm damage in hedged and nonhedged treatments from 2015-17.

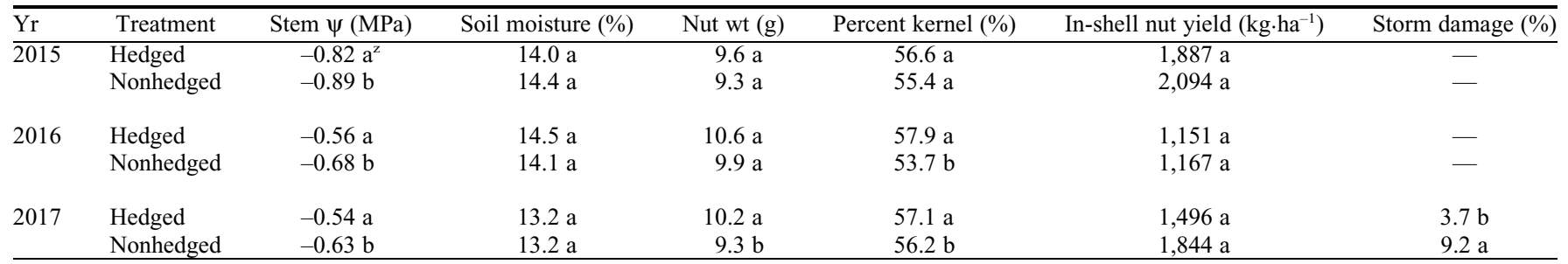

${ }^{\mathrm{z}}$ Means followed by the same letter within each year are not different at $P<0.05$ by Tukey's honestly significant difference test. 
A

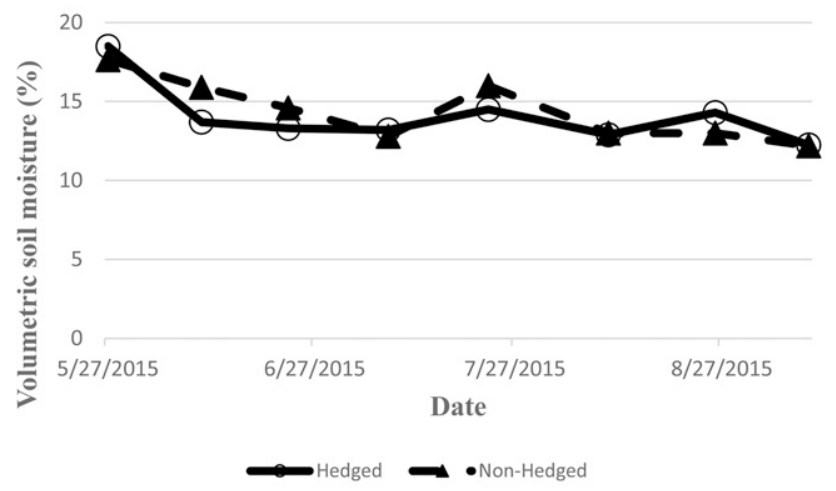

B

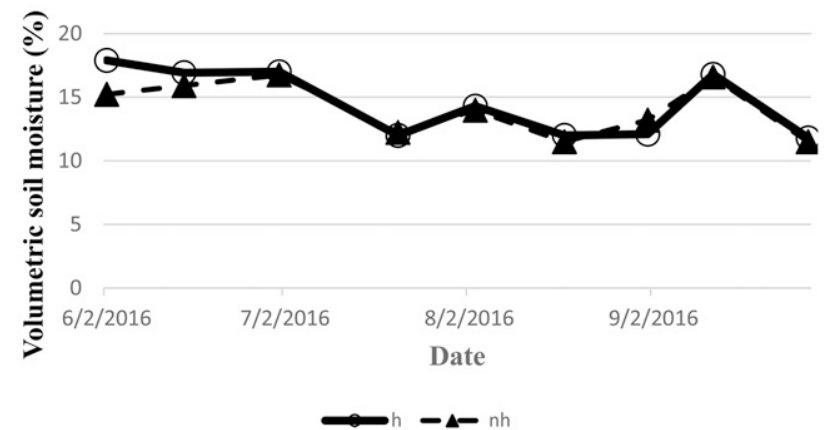

C

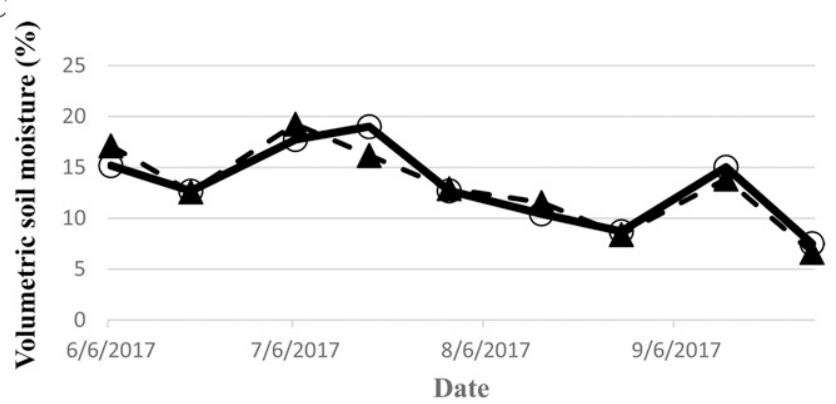

Fig. 3. Mean volumetric soil moisture (\%) adjacent to hedged and nonhedged 'Desirable' pecan trees during 2015,2016 , and 2017.

size has been linearly related to the average midday stem $\psi$, with larger trees having a more negative water potential (Shackel et al., 2000). Because water moves from an area of high to low water potential as it moves from the roots to the foliage, there should be less force exerted by the transpirational stream as the root: shoot ratio increases. Vapor pressure deficit (VPD) is a function of air humidity and temperature and is linearly related with stem $\psi$ (McCutchan and Shackel, 1992). Although VPD was not measured in the present study, the high temperatures and high relative humidity characteristic of southern Georgia would be expected to generate more favorable VPD and stem $\psi$ values than those found in more arid conditions.

Deb et al. (2012) found lower values of stem $\psi$ associated with tree heights within individual tree canopies, most likely resulting from the resistance to liquid water flow in the longer pathway to the uppermost leaves (Begg and Turner, 1970; Hellkvist et al., 1974). The same factors may also help to explain the lower stem $\psi$ found in nonhedged vs. hedged pecan trees because hedged trees were smaller in height and overall size than nonhedged trees. These vertical differences might also be related to the absorption and partitioning of radiation within the canopy, which may reflect the degree of exposure leaves to solar radiation, as Deb et al. (2012) suggested for within-canopy characteristics.

Nut weight and percent kernel were increased $(P \leq 0.05)$ by hedge pruning 2 of 3 years of the study (Table 2 ). Similar results have been observed in previous pruning studies (Wood, 2009; Worley and Mullinix,
1997). Soil water availability is widely recognized as the single most important abiotic factor affecting nut weight and kernel quality (Sparks, 2001). Previous studies have documented improved fruit size and quality of tree fruit crops including pecan, with less negative stem water potential (Naor et al., 1995; Wells, 2015). Therefore, it is likely that the effect of hedge pruning on nut weight and percent kernel is related to the improved water status of hedged trees compared with nonhedged trees.

The increased source: sink ratio associated with a reduction in fruit load can affect plant water relations (Marsal et al., 2006, 2008; Naor et al., 1995; Sadras and Trentacoste, 2011). This is often reflected in the increased nut weight and percent kernel observed in trees that are mechanically fruit thinned (Smith and Gallot, 1990; Smith et al., 1993; Wells et al., 2009). Based on in-shell pecan yield and nut weight, the nonhedged trees averaged $\approx 20 \%$ more nut volume than hedged trees. Reducing canopy size also has the potential to affect plant water relations. In the present study, hedge pruning reduced the size of the tree canopy by $\approx 33 \%$ in the year of pruning. As both nut volume and canopy are reduced, trees should have more resources, including water, available for optimal development of remaining nuts. In addition, hedge pruning results in an increased flush of foliage growth (Lombardini, 2006; Wood, 2009), which would further influence the source: sink ratio in favor of hedged trees.

This study supports the results of Lombardini (2006), in that there were no differences in in-shell nut yield between hedged and nonhedged trees (Table 2). Wood (2009) found that hedge pruning of pecan resulted in a $19 \%$ to $38 \%$ reduction of in-shell nut yield in Georgia; however, the trees in that study were planted at a higher density than that of the present study. As would be expected with the present study, Wood (2009) suggested that shading would eventually lead to reduced yield of nonpruned trees as orchards continued to crowd. A more long-term study is required to determine if and when these yield reductions would occur and whether hedge pruning would help to mitigate these yield reductions.

Hurricane Irma brought damaging winds to the entire pecan-producing region of Georgia on 11 Sept. 2017, resulting in blown down trees, broken branches, and immature nuts blown from the trees. Maximum wind speeds reached $81.54 \mathrm{~km} \cdot \mathrm{h}^{-1}$ at the weather station located $\approx 5.3 \mathrm{~km}$ from the study site. Hedged trees had $60 \%$ less $(P<0.05)$ wind damage in the form of major limb breakage and tree loss than did nonhedged trees (Table 2). It is likely that the reduced tree height, more compact limb structure, and reduced canopy size of hedged trees helped reduce the surface area of tree exposure to damaging winds. Hedge pruning and other pruning methods that reduced tree height and opened up canopies greatly reduced limb breakage and uprooting of trees of tropical fruit species exposed to hurricane Andrew in south Florida (Campbell et al., 1993). Gilman et al. (2008) suggested that reducing the length of certain branches helps create a lower center of gravity on those branches and might help contribute to their survival in windstorms and that reducing the entire crown 
size would also reduce damage potential. Wood et al. (2001) theorized that using hedge pruning techniques should keep tree height low and orchard canopy relatively dense, thus minimizing tree exposure to winds and the associated leveraging effect on root systems.

\section{Summary}

The results of this study suggest that hedge pruning of pecan trees in the southeastern United States can be beneficial to tree water status, nut weight, nut quality, and windstorm resistance. Previous studies have shown the reduced tree size resulting from hedge pruning of pecan can enhance pecan scab disease control in the southeastern United States (Bock et al., 2017). The present study suggests that this reduced tree size also minimizes tree water stress as measured by the pressure chamber, increasing stem $\psi$ by an average of $14 \%$. This, along with the resulting shifts in source: sink ratio, helps to enhance nut weight and kernel percentage on hedged trees.

Although no direct positive effect of hedge pruning on in-shell nut yield was observed, hedge pruning was not detrimental to pecan yield in the short term. In fact, hedging would likely create a more marketable nut with increased weight and kernel percentage. In addition, the increased resistance to wind damage in storms provides a further benefit to hedge pruning of pecan in the southeastern United States.

\section{Literature Cited}

Alben, A.O. 1957. Results of an irrigation experiment on Stuart pecan trees in East Texas in 1956. Proc. Texas Pecan Growers Assn. 36:16-23.

Andales, A., J. Wang, T.W. Sammis, J.G. Mexal, L.J. Simmons, D.R. Miller, and V.P. Gutschick. 2006. A model of pecan tree growth for the management of pruning and irrigation. Agr. Water Mgt. 84:77-88.

Begg, J.E. and N.C. Turner. 1970. Water potential gradients in field tobacco. Plant Physiol. 46:343-346.

Bock, C.H., M.W. Hotchkiss, T.B. Brenneman, K.L. Stevenson, W.D. Goff, M.W. Smith, L. Wells, and B.W. Wood. 2017. Severity of scab and its effects on fruit weight in mechanically hedge-pruned and topped pecan trees. Plant Dis. 101:785-793.

Brison, F.R. 1974. Pecan culture. Capital Printing, Austin, TX.
Campbell, R.J., C.W. Campbell, J. Crane, C. Balerdi, and S. Goldweber. 1993. Hurricane Andrew damages tropical fruit crops in south Florida. Fruit Var. J. 47:218-225.

Daniell, J.W., R.B. Moss, and B. Deal. 1979. The use of irrigation in pecan orchards. Pecan South 6:84-85.

Deb, S.K., M.K. Shukla, and J.G. Mexal. 2012 Estimating midday leaf and stem water otentials of mature pecan trees from soil water content and climate parameters. HortScience 47:907-916.

Gilman, E.F., F. Masters, and J.C. Grabosky. 2008. Pruning affects tree movement in hurricane force wind. Arboric. Urban For. 34:20-28.

Hellkvist, J., G.P. Richards, and P.G. Jamis. 1974. Vertical gradients of water potential and tissue water relations in Sitka spruce trees measured with the pressure chamber. J. Appl. Ecol. 11:637-668

Herrera, E. and J.M. White. 2000. Pruning mature trees. New Mexico State Univ. Guide H-629.

Hudson, W., J. Brock, S. Culpepper, and L. Wells. 2017. Georgia pecan pest management guide. Univ. Georgia Coop. Ext. Bull. 841.

Lombardini, L. 2006. One-time pruning of pecan trees induced limited and short term benefits in canopy light penetration, yield, and nut quality. HortScience 41:1469-1473.

Marsal, J., G. Lopez, M. Mata, and J. Girona. 2006. Branch removal and defruiting for the amelioration of water stress effects on fruit growth during stage III of peach fruit development. Scientia Hort. 108:55-60.

Marsal, J., M. Mata, A. Arbones, J. Del Campo, J. Girona, and G. Lopez. 2008. Factors involved in alleviating water stress by partial crop removal in pear trees. Tree Physiol. 28:13751382.

McCutchan, H. and K.A. Shackel. 1992. Stem water potential as a sensitive indicator of water stress in prune trees (Prunus domestica L. cv. French). J. Amer. Soc. Hort. Sci. 117:607-611.

Naor, A., I. Klein, and I. Doron. 1995. Stem water potential and apple fruit size. J. Amer. Soc. Hort. Sci. 120:577-582.

Othman, Y., D. Van Leeuwen, R. Heerema, and R. St. Hilaire. 2014. Midday stem water potential values needed to maintain photosynthesis and leaf gas exchange established for pecan. J. Amer. Soc. Hort. Sci. 139:537-546.

Pearce, S.C. and S. Dobersek-Urbanc. 1967. The management of irregularity in growth and cropping. J. Hort. Sci. 42:295-305.

Sadras, V.O. and E.R. Trentacoste. 2011. Phenotypic plasticity of stem water potential correlates with crop load in horticultural trees. Tree Physiol. 31:494-499.

Shackel, K.A., B. Lampinen, S. Sibbett, and W. Olson. 2000. The relation of midday stem water potential to the growth and physiology of fruit trees under water limited conditions. Acta Hort. 537:425-430.

Smith, M.W. and J.C. Gallot. 1990. Mechanical thinning of pecan fruit. HortScience 25:414 416.

Smith, M.W., W. Reid, B. Carroll, and B. Cheary. 1993. Mechanical fruit thinning influences fruit quality, yield, return fruit set, and cold injury of pecan. HortScience 28:1081-1084.

Sparks, D. 2001. Managing pecan nut growth. Proc. S.E. Pecan Growers Assn. 94:129-147.

Stein, L.A., G.R. McEachern, and J.B. Storey. 1989. Summer and fall moisture stress and irrigation scheduling influence pecan growth and production. HortScience 24:607-611.

Stevenson, T. 2013. Hedging in the southeast. Pecan Grower 24:28-31.

U.S. Department of Agriculture. 2012. Noncitrus fruits and nuts: 2011 summary. Natl. Agr. Stat. Serv., U.S. Dept. Agr., Washington, DC

Wang, J., D.R. Miller, T.W. Sammis, V.P. Gutschick, and L.J. Simmons. 2007. Energy balance measurements and a simple model for estimating pecan water use efficiency. Agr. Water Mgt 91:92-101

Wells, M.L. (ed.). 2007. Southeastern pecan growers handbook. Publ. 1327. Univ. Georgia Coop. Ext. Ser., Athens, GA

Wells, M.L. 2014. Pecan planting trends in Georgia. HortTechnology 24:475-479.

Wells, M.L. 2015. Irrigation water management for pecans in humid climates. HortScience 50:1070-1074.

Wells, M.L. 2017. Pecan water requirements and irrigation scheduling. Univ. Georgia Coop. Ext. Circ. 1106.

Wells, M.L., D.S. Carlson, and R.P. Edwards. 2009 Profitability of mechanical fruit thinning of 'Sumner' and 'Cape Fear' pecan. HortTechnology 19:518-520.

Wood, B.W. 1996. Establishing pecan transplants. HortTechnology 6:276-279.

Wood, B.W. 2009. Mechanical hedge pruning of pecan in a relatively low-light environment. HortScience 44:68-72.

Wood, B.W., W. Goff, and M. Nesbitt. 2001 Pecans and hurricanes. HortScience 36:253258.

Wood, B.W. and D. Stahmann. 2004. Hedge pruning pecan. HortTechnology 14:63-72.

Worley, R.E. 1982. Tree yield and nut characteristics of pecan with drip irrigation under humid conditions. J. Amer. Soc. Hort. Sci. 107:30-34.

Worley, R.E. 1985. Effects of hedging and selective limb pruning of Elliott, Deisrable, and Farley pecan trees under three irrigation regimes. J. Amer. Soc. Hort. Sci. 110:12-16.

Worley, R.E. and B. Mullinix. 1997. Selective limb pruning of large pecan trees reduces yield but improves nut size and tree characteristics. HortScience 32:50-52. 